Faculdade

de Ciências Econômicas UFRGS

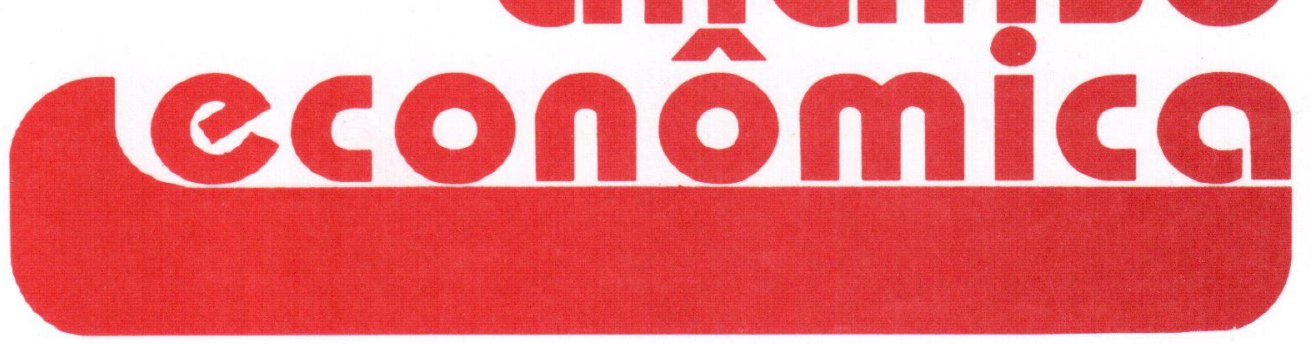

Balança Comercial e Capacidade

Produtiva da Indústria de Transformação

- Flávio Benevett Fligenspan

- Jeferson Luis Bittencourt

Breves Reflexões sobre a Relevância

da História da Teoria Econômica

- Gilberto Tadeu Lima

A Competitividade do Arroz Gaúcho

e seus Condicionantes

- Augusto M. Alvim

- Carlos G. A. Mielitz Netto

Uma Análise da Economia de Ricardo

- Liderau S. Marques Junior

A Estratégia de Substituição de

Importações Revisitada

- Alex Pereira Benício

- Joanílio Rodolpho Teixeira

The Refinements of the Orthodox Macroeconomic Theory and the Post Keynesian Theory

- Fernando Ferrari Filho

Instrumentos de Gestão Ambiental

- Jaildo Santos Pereira

- Vitor Emanuel Tavares

The Economic Implications for

Sustainable Mining

- Dina Franceschi

- James R. Kahn

Mudança Institucional e Estrutural na

Economia Brasileira do Início dos Anos Noventa

- Eduardo Simões de Almeida
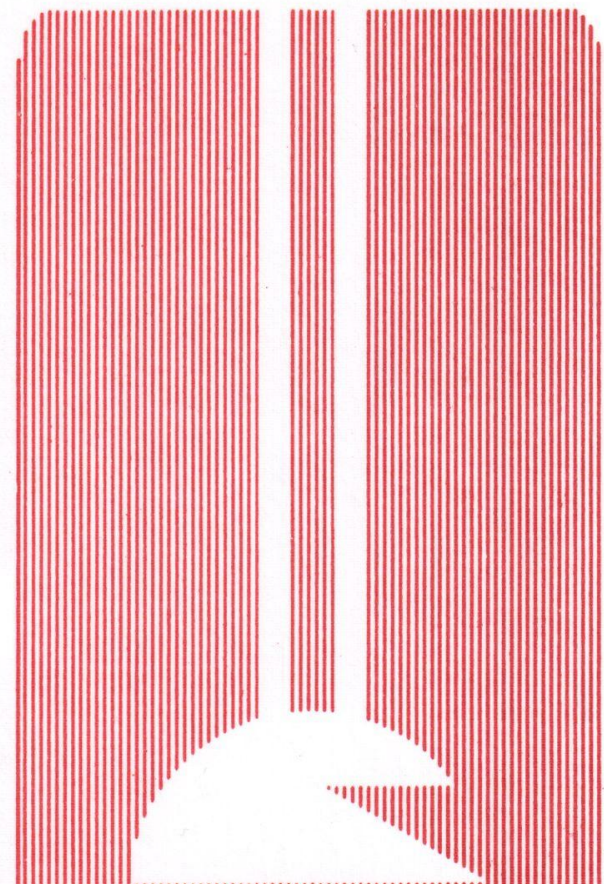

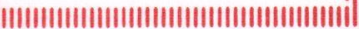
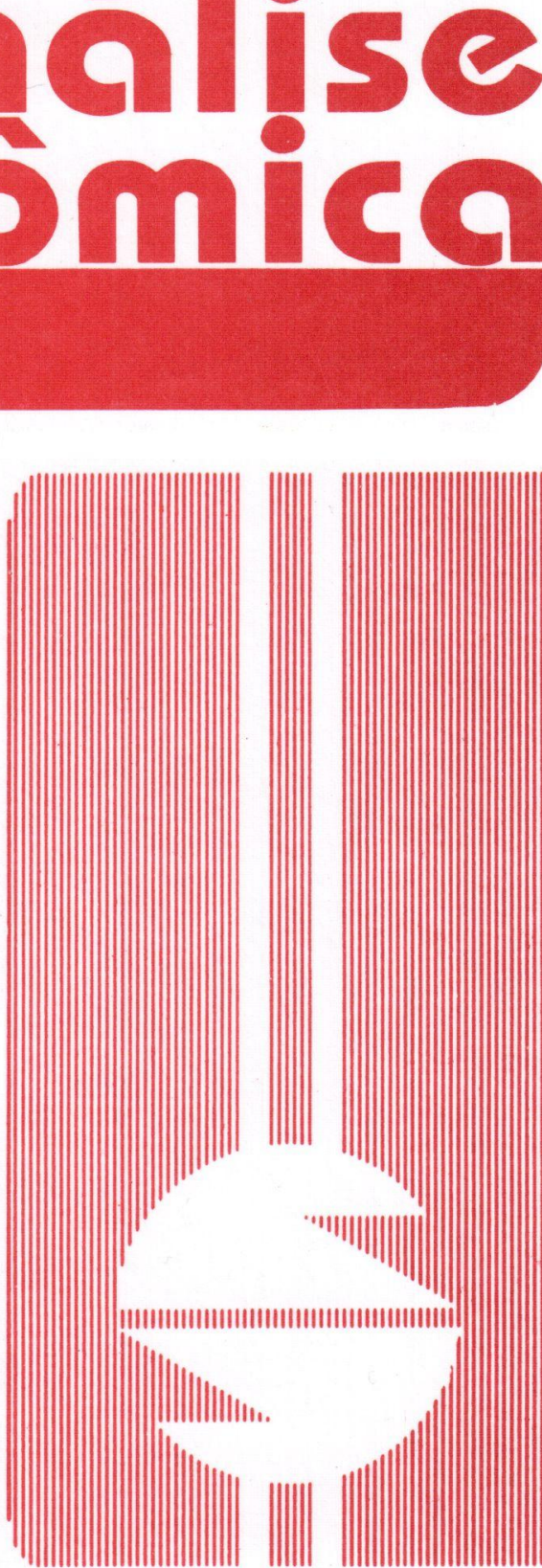
UNIVERSIDADE FEDERAL DO RIO GRANDE DO SUL

Reitora: Prof ${ }^{a}$. Wrana Maria Panizzi

FACULDADE DE CIÊNCIAS ECONÔMICAS

Diretora: Prof . Otilia Beatriz Kroeff Carrion

CENTRO DE ESTUDOS E PESQUISAS ECONÔMICAS

Diretor. Prof. Fernando Ferrari Filho

DEPARTAMENTO DE CIÊNCIAS ECONÔMICAS

Chefe: Prof. Luiz Alberto Oliveira Ribeiro de Miranda

CURSO DE PÓS-GRADUAÇÃO EM ECONOMIA

Coordenador. Prof. Marcelo Savino Portugal

CURSO DE PÓS-GRADUAÇÃO EM ECONOMIA RURAL

Coordenador. Prof. Carlos Guilherme A. Mielitz Netto

CONSELHO EDITORIAL: Achyles B. Costa, Aray M. Feldens, Carlos A. Crusius, Carlos G. A. Mielitz Netto, Eduardo A. Maldonado Filho, Eduardo P. Ribeiro, Eugênio Lagemann, Fernando Ferrari Filho, Gentil Corazza, Marcelo S. Portugal, Nali J. Souza, Otília B. K. Carrion, Paulo A. Spohr, Paulo D. Waquil, Pedro C. D. Fonseca, Roberto C. Moraes, Ronald Otto Hillbrecht, Stefano Florissi, Eleutério F. S. Prado (USP), Fernando H. Barbosa (FGV/RJ), Gustavo Franco (PUC/RJ), João R. Sanson (UFSC), Joaquim P. Andrade (UnB), Juan H. Moldau (USP), Paul Davidson (Univ. of Tennessee), Werner Baer (Univ. of lllinois).

COMISSÃO EDITORIAL: Eduardo Augusto Maldonado Filho, Fernando Ferrari Filho, Gentil Corazza, Marcelo Savino Portugal, Paulo Dabdab Waquil; Roberto Camps Moraes.

EDITOR: Gentil Corazza

EDITOR ADJUNTO: Pedro Silveira Bandeira

SECRETARIA: Fábio Sparremberger. Revisão de textos: Vanete Ricacheski.

FUNDADOR: Prof. Antônio Carlos Santos Rosa

Os materiais publicados na revista Análise Econômica são da exclusiva responsabilidade dos autores. É permitida a reprodução total ou parcial dos trabalhos, desde que seja citada a fonte. Aceita-se permuta com revistas congêneres. Aceitam-se, também, livros para divulgação, elaboração de resenhas e recensões. Toda correspondência, material para publicação (vide normas na terceira capa), assinaturas e permutas devem ser dirigidos ao seguinte destinatário:

PROF. GENTIL CORAZZA

Revista Análise Econômica - Av. João Pessoa, 52 CEP 90040-000 PORTO ALEGRE - RS, BRASIL 


\title{
THE ECONOMIC IMPLICATIONS FOR SUSTAINABLE MINING WITHIN THE PARADIGM OF SUSTAINABLE DEVELOPMENT ${ }^{1}$
}

\author{
Dina Franceschi * \\ James R. Kahn
}

\begin{abstract}
This paper will discuss the concept of sustainability in terms of its economic implications, with specific emphasis on the ramifications for the mining sector in Brasil. It will examine this perspective through a review of conceptual approaches to exhaustible resource sustainability and describe it's relationship to the more general definition of sustainable development. Additionally, it will offer suggestions of how to operationalize the concept of sustainable development so that the criterion of sustainability can become a real aspect of the decision process
\end{abstract}

AEA Code: 722

Key Words: Sustainable development, sustainability, environment, natural resources

\section{RESUMO}

Este texto visa discutir o conceito de sustentabilidade em termos de suas implicações econômicas, com especial ênfase nas ramificações do setor mineiro no Brasil . Pretende-

se examinar esta perspectiva através de uma revisão das abordagens conceituais à sustentabilidade dos recursos exauriveis e descrever sua relação com uma definição geral do desenvolvimento sustentável. Adicionalmente visa-se oferecer sugestões relati-

vas à operacionalização do conceito de desenvolvimento sustentável de modo que o critério de sustentabilidade possa tornar-se um aspecto real do processo decisório.

Cód. AEA: 722

Palavras-Chave: Desenvolvimento sustentável, sustentabilidade, meio ambiente, recursos naturais

1 Prepared for Mineração e Desenvolvimento Sustentável (Sustainable Development and Mining) Ouro Preto Workshop, Brasil March 23-25, 1998. The authors would like to thank Laura Barreto, Monica Peres Menezes, Carlos Peiter, and Roberto Villas Boas for helpful comments.

"Department of Economics and National Center for Environmental Decision Making Research University of Tennessee, Knoxville, TN 37966-0550 (423)-974-3303 dfrance1@utk.edu

Department of Economics and National Center for Environmental Decision Making Research University of Tennessee, Knoxville, TN 37966-0550 and Oak Ridge National Laboratory, Oak Ridge, TN (423)-974-1699 jkahn@utk.edu.
Análise Econômica
ANO 17
N. 31
Março/99
p. 141-154 


\section{1 - INTRODUCTION}

The term and concept of sustainable development had gotten much attention since the late 1980's, when it became the theme for planned economic growth around the world. The definition of the terms has been molded to fit different situations since then, but has mostly retained the original thrust behind which sustainable development is driven. Generally, the interpretation relates "improving the prospects of the current generation without reducing the prospects of future generations". 2 This implies the potential for economic growth and standard of living increases for today's society, while preserving the potential for future societies to continually grow and live better, as well. But many hold a more specific definition of sustainable development in mind with a greater emphasis on natural resources. Some feel that providing a sufficient level of environmental resources to future generations is the central issue in leaving options for development open to them. This idea puts a greater weight on the necessity of basic inputs to living and production than on the technological advances used to produce goods. With this definition, the roles of exhaustible resources or mining products and environmental resources or ecosystem products are at the very heart of the discussion of sustainability.

\section{2 - TRADITIONAL APPROACHES}

The conventional treatment of exhaustible resources in terms of sustainability dates back to the early works of Thomas Malthus (1822) and David Ricardo (1817), where resource scarcity and diminishing returns dominated the analysis. These models focused on finite resource supply and whether continued economic growth was possible if resources became more scarce. Work by Barnett and Morse (1963) built on these ideas by emphasizing the relationship between increasing scarcity and price, and the feedback of this relationship in mitigating scarcity. By basing their model on an assumption of free substitution of inputs, namely labor, capital and exhaustible resources, Barnett and Morse found that new technology and it's efficiency effects in terms of cost reduction, greatly outweighed the cost increasing effects of depletion. These influential findings largely refuted the previously held notion that limits to growth existed and a collapse of society was inevitable at current consumption and development rates. Since Barnett

2 For more reading on the basic concept of sustainable development one can turn to the original Brundtland Commission Report (World Commission on Environment and Development, 1987), or works by Robert Solow (1992), David Pearce (1993), and John Pezzey (1989) 
and Morse's conclusions, other models of sustainability and intertemporal exhaustible resource use have been formulated. For example, works by John Hartwick (1977,1993, 1994), John Pezzey (1989) and others expand on the same basic premise.

But, the assumption of substitutability between inputs is not an inconsequential one. The foundation of the Barnett and Morse work is built on the interchangeability between human capital (the quantity and quality of the labor force), human-made capital (such as machines, roads and factories), and extractable natural resources (such as metals, fossil fuels and timber) as inputs to the production process. Two issues regarding substitution to achieve sustainability in these models are of primary concern. The two issues concern the role of environmental resources as an input to the production process and market failure in the provision of environmental resources.

The first issue arises because these economic models leave out the environmental or ecological resources input component to the production process. Ecological resources provide an array of important services to a variety of different production processes, including traditional economic production processes (industrial, agricultural, etc.), ecological production processes, and direct impacts on day-to-day living and the quality of life.

The exclusion of environmental resource as inputs to the production process is compounded by the assumption of perfect substitutability of all inputs. Even if there were a representation of the quality or quantity of environmental resources in a steady state or sustainability model, the assumption of substitutability would render the models ill-suited for examining issues of sustainability. Because of the inherent complexity of ecological systems, particularly those in the tropical climates, it is not realistic to assume that other inputs are good substitutes. The ecological services produced by a complex ecosystem cannot be easily replaced by the application of other inputs such as human-made capital, human capital or extractible resources. This is both an issue of the large scale of the natural provision of ecological services $^{3}$ and because of a lack of understanding of ecological complexity and the factors that determine ecological resilience and productivity. In addition, there is a very incomplete understanding of the role of ecological services in economic production processes, so even if replication were possible, the question would remain, what ecological services should be replicated. The above arguments indicate that human-made capital, human capital and

\footnotetext{
${ }^{3}$ Imagine the number of "ecological service factories" that would be necessary to process the nutrients that are cycled by a large forest or wetland system, what it would take to produce oxygen on the same scale as the world's tropical forests and the oceans' phytoplankton layer, or the size of the zoos and botanical gardens necessary to preserve the biodiversity of the tropical rainforests.
} 
exhaustible resources cannot, to a significant degree, substitute for ecological services in production. In particular, human-made capital cannot replace ecological services in production.

This lack of knowledge of ecosystem complexity, resilience, stability and productivity makes the task of including ecological resources in the analysis of sustainability all the more challenging, but also heightens the responsibility.

As a reminder, the generally accepted definitions of sustainability require the current generation to satisfy their needs without reducing the prospects for future generations. The above discussion indicates that the conservation of environmental resources and ecological services may be more important to maintaining these prospects than the conservation of extractible resources or even the accumulation of human-made capital.

As noted above, the second issue concerning environmental resources arises because of market failure. The traditional approach to the rationing of exhaustible resources is based on the premise that the market can allocate supply and usage through the pricing system. In the classic literature of resource scarcity, including the work by Barnett and Morse, as an exhaustible resource or mineral resource base becomes depleted, prices rise. The rise in price is primarily the response of increased costs of extraction of the relatively less abundant source (relative in the sense of the deposit being less rich than deposits of the past). As price of one extractible resource rises, either firms find better extraction technology to control costs or buvers switch to another product that can satisfy their needs at a lower price. In the case of environmental or ecological resources, the market is unable to signal scarcity or ration usage. Most often ecological systems do not have prices associated with their services, because they are external to markets. The public goods nature of ecosystems, which includes the properties of non-rivalry and non-excludability, precludes sustainable long term usage. ${ }^{4}$ Again, the fact that these systems are exceptions to the classic economic rules heightens the need for their explicit inclusion in policies to promote sustainability.

\section{3 - SUSTAINABLE MINING}

Mining processes have long been thought to be very harmful to the environment and generally not sustainable in the long run. Much of this mind set is due to a history of inhospitable mining operations around the world and in Brasil. In the past, not unlike other industries, the mining industry has

\footnotetext{
${ }^{4}$ Non-rival means that one person's consumption of a public good does not reduce the amount of that good available for other people's consumption. Non-excludable means that if a public good is available for one person it is available for all others as well.
} 
used little caution with regard to the land and forest that was cleared for construction, the water that was used in the production process and disposed of without treatment, the air pollution that was emitted, and the tailings and leachates which released harmful toxins into the earth. But this history of degradation and depletion need not define the role of mining in terms of sustainability for the present and the future.

Economic reliance on exhaustible resources does not necessarily mean an unsustainable growth path. Typically mining profits are thought to be relevant over the time horizon of the mining project, then disappear as quickly as the deposit itself. It is not a necessity that short term gains are the only contribution of mining to the economy, a broader view of this relationship may provide a more optimistic view. The revenues received in the current period from mining operations in Brasil are substantial. The forecasted potential revenues from mining in the near future are considerable as well. High earnings today, if used wisely, can help offset reliance on other economic activities that are less sustainable than mining. For instance, subsistence, slash-and-burn type, agricultural practices in the Amazonian forest region are only sustainable, economically, for 2 or 3 years due to the rapid depletion of nutrients from the soil (Caviglia, 1998). An increase in mining activity could replace reliance on this style of living by providing jobs for those otherwise unemployed, or by providing capital to those who need better equipment, seeds or fertilizer to farm land more efficiently and longer term. No general conclusions have been made to date regarding the relative sustainability of renewable extraction compared with non-renewable extraction. But it is likely that extractive uses of renewable resource systems (e.g. unsustainable forestry, unsustainable intensive agriculture and open-access fishing practices) are less sustainable than extraction of non-renewable resources. If mining can direct economic growth away from the less sustainable activities, the effects of current period profits will have implications for many years into the future.

Even without coricrete quantitative analysis, qualitative comparison of economic activities can result in conclusions regarding environmental impacts. Mining operations, in many cases, leave a smaller ecological footprint over time than alternative land uses, particularly with regard to ecological services. Take again, a simplified version of the comparison of mining to agriculture. For illustrative purposes, one could look solely at the impact of each productive process with regard to it's effect on deforestation. The mining enterprise in the forest would initially need to clear the land by removing trees and undergrowth, build roads and other facilities, but then most of the impact is in digging down into the earth. A farming operation would also clear the trees first. But after two or three years of viable farming, the farmer would need to abort the original farming plot for another, where clearing 
would then occur again. The original farming land could then perhaps be used for cattle grazing for another four or five years, and after that abandoned. A comparable portion of ground then is used for an upper limit total of eight years as productive farm/grazing land, or for an upper limit total of twenty or more years, depending on the life of the ore deposit.

The focus here on deforestation or equivalently, the depletion of an entire bunble of ecological services, points directly to the basic definition of sustainability. As opposed to pollution or point source emissions, environmental impacts on complete health more directly affects long term welfare or the people or communities which functions within them. Over the past few decades, we have gotten relatively efficient at controlling point source pollutants. The technology is availabie air and water emissions to diminimus levels and in most cases legal controls for pollution are among the variety of regulations with which industry must comply, in both developed and developing countries. Ecosystems are also very resilient in themselves. Small, controlled impacts on a limited number of ecological variables does not mean ecosystem collapse. Internal recovery and compensation mechanisms allow ecosystems to recover through natural mechanisms when a natural or man-made shock occurs. Conversely, large scale shocks, such as completely clearing large portions of forest, more likely would mean the transformation of that area to another ecosystem type, for example, infertile grassland or scrub.

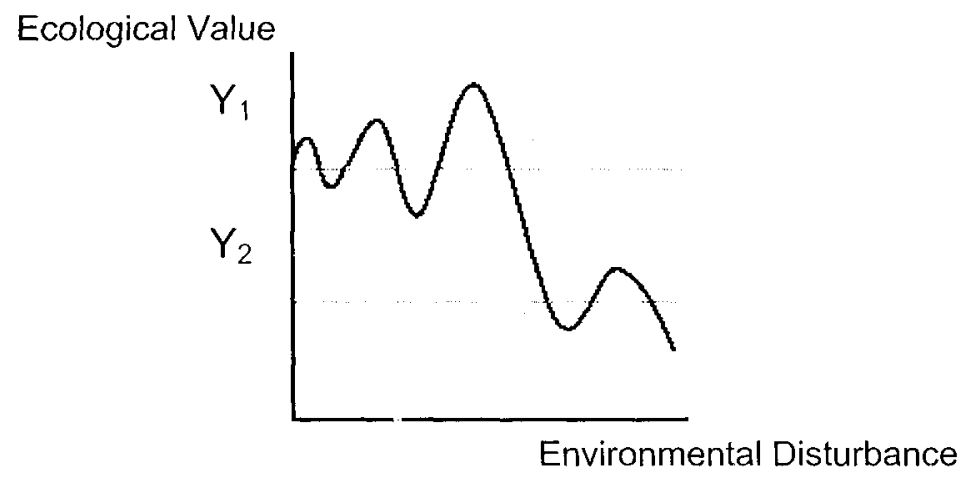

Figure 1. Ecological Instability

Figure 1 illustrates the natural oscillation of ecosystem health around an equilibrium when effected by disturbances. The $y$-axis variable implies the difference in biological diversity and richness between say, tropical forest and grassland ecosystems. With some major disturbance or irrecoverable impact, the equilibrium becomes a different one entirely, a new ecosystem 
type takes over (see Kahn and O'Neill). Figure 2 shows the non-linear relationship damages can have with disturbances. Low levels of damages, corresponding with small pollution emission type impacts (or small changes in land use), result in low levels of disturbances and potentially high levels of ecosystem recovery. But, as damages increase, disturbances escalate exponentially, likely causing irreversible change in an ecosystem. In terms of ecological services and sustainability, environmental impacts on ecological resource systems are more important than pollution emissions, except to the extent that pollution emissions grossly impact the ability of ecosystems to provide ecological services. Through generally geographically smaller (though more intense) land use impacts, mining operations may in fact impact ecological resource systems less than other economic activities.

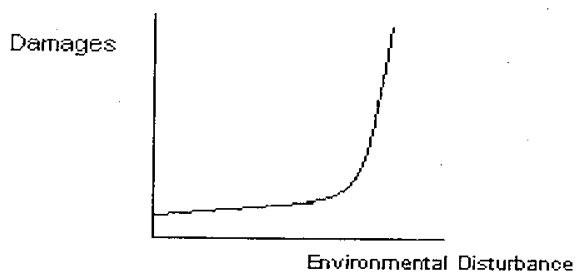

Figure 2. Exponential Damages

\section{4 - THE ENVIRONMENT, ECONOIMY AND WELFARE}

In many studies which examined the relationship between the environment and the macroeconomy, environmental quality and GDP were thought to be inversely related. If environmental quality is viewed to be obtained through emission reductions, then resources devoted to reducing emissions cannot be used to produce GDP. Figure 3 demonstrates this traditional production possibilities frontier, where a direct tradeoff between the two is clearly defined. Many studies examining the relationship between the economy and the environment have been based upon an assumption of this direct trade-off, including Jorgenson and Wilcoxen (1990) and Hazilla and Kopp (1990).

The more recent findings however, suggest that environmental quality is an important input in the production process and therefore an input to GDP. For example, Gillis et al (1996) show that the impact of improved environmental quality on worker productivity through improved health dominates the direct trade-off between the environment and GDP which is discussed above. 


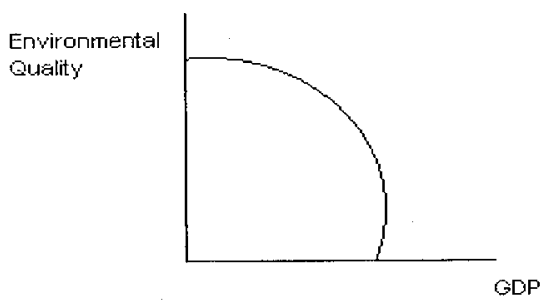

Figure 3 - Conventional Perspective of the production possibilities frontier

Figure 4 shows a revised relationship between environmental quality and GDP. Here, as the economy is in it's infancy, beginning as an agricultural society, environmental quality does not decline as the environment has assimilative capacity. Environment quality may even increase as initial levels of waste outputs enhance the natural environment (such as increasing the nutrients in nutrients impoverished ecosystem) or as initial forest clearing activity creates new habitat and increases biodiversity.

As the economy then grows, making the transition to a larger scale agricultural society or to industrial society, environmental quality begins to decline with added stresses from pollution and resource use. Further, there is likely to be a turning point in the relationship where extremely low levels of environmental quality perversely effect the rate of growth of GDP and further attempts to increase GDP result in reduced environmental quality, causing a downward spiral in the economic productivity of the society. This is probably the position that many Sub-Saharan African countries find themselves in ${ }^{5}$. A similar situation probably exists in many areas of Eastern and Central Europe. ${ }^{6}$

${ }^{5}$ This is due to attempts to increase output by placing more livestock on the grassland, which causes overgrazing, destruction of woody plants, and the conversetion of grassland to desert.

${ }^{6}$ This is due to heavy levels of industrial pollution which have poisoned streams and soil, and generated extreme health consequences for large portions of the population. 


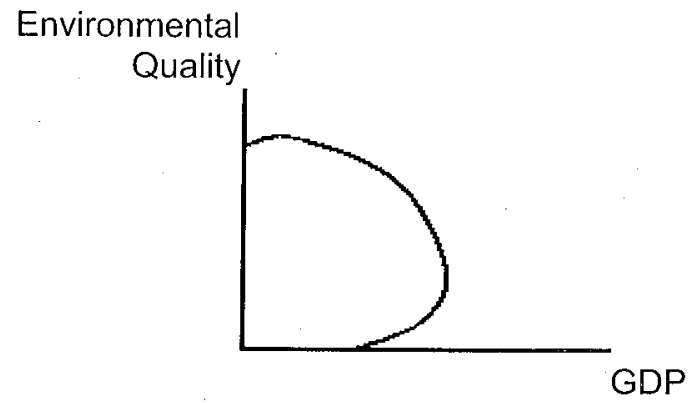

Figure 4 - Production possibilities frontier when environmental quality is an input in producing GDP

Social welfare or a nation, as illustrated in Figure 5, is a function of many components. It depends on the health of the population, of the economy, and of the environment, and on social justice. In terms of sustainability, all are equally important. The health of the population is important to provide the essencial input of human capital to production processes. The relationship between human health and environment quality is often overlooked. Here too, environmental quality provides a necessary input to human health, through sanitation and clean water by limiting disease and providing clean air to breath. The social justice component is also often forgotten in the discussion of sustainability of social systems. Institutions such as governments, education, families, religious organizations and non-governmental entities must evolve to adequately promote and maintain sustainable activities.

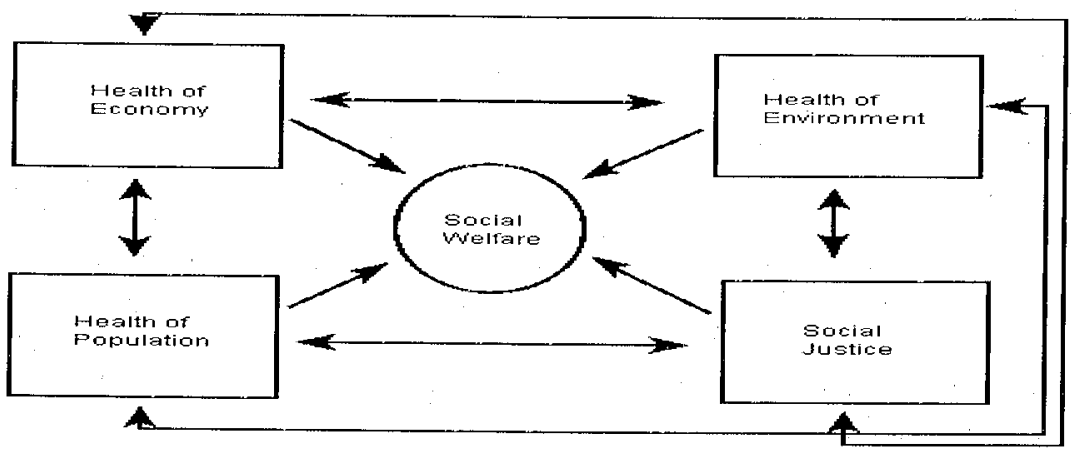

Figure 5 - Selected determinants of social welfare

It is important to note that operational indicators exist for most categories of social impact defined in Figure 5. For example, GDP, the inflation rate 
and the unemployment rates are all indicators of the health of the economy. None of these indicators are perfect or without bias, for example, the unemployment rate does not include people who have become so discouraged they have ceased looking for jobs. However, if the shortcomings of the indicators are understood, they can still be informative for policy purposes. Similarly, we have operational indicators for the health of the population (longevity, infant mortality, etc.) and for social justice (inequality of income distribution, literacy rates, differential incarceration rates, etc.). However, we have yet to construct a useful and widely accepted set of operational indicators of the health of the environment or of sustainability.

The importance of developing such operational indicators of environmental quality can be emphasized with a mathematical representation (Equation (1)) of the functional determinants of social welfare (SW), which were modeled in Figure 5 . In this equation, the full set of functional determinants of GDP, environmental quality (EQ), the health of the population (POP) and social justice (SJ) are suppressed to focus on the role of environmental quality in determining social welfare, particularly through its impact on GDP.

$$
S W=f[G D P(E Q, P O P), E Q, P O P(E Q), S J]
$$

Focusing on the economy-environment inputs to social welfare, the change in social welfare caused by a change in environmental quality would further look as follows:

$$
\frac{d S W}{d E Q}=\frac{\partial S W}{\partial G D P} \frac{\partial G D P}{\partial E Q}+\frac{\partial S W}{\partial G D P} \frac{\partial G D P}{\partial P O P} \frac{\partial P O P}{\partial E Q}+\frac{\partial S W}{\partial P O P} \frac{\partial P O P}{\partial E Q}+\frac{\partial S W}{\partial E Q}
$$

Specifically, social welfare changes occur through changes in GDP and environmental quality. Note however, environmental quality not only affects social welfare directly, but also through the GDP function, both directly and through its impact of the health of the population. While we cannot estimate the social welfare function, we can gain insight from indicators, especially if we can use indicators to measure the functional relationship between environmental quality and GDP, and environmental quality and the health of the population. Thus, it is important to develop indicators not only to measure the status of the health of the environment, but also to give insight in the functional relationships described in Equation (2).

\section{5 - AN INTEGRATED APPROACH}

The importance of developing environmental indicators has been recognized, and several programs such as The US EPA's Environmental Monitoring and Assessment Program (EMAP) and the "Green National Ac- 
counting Program" of the United Nations have begun. The approach of these programs has been to define a set of key environmental variables and track their performance over time. These initial attempts have limited policy applications however. Tradeoffs are difficult, if not impossible to examine when there are literally thousands of environmental indicators. In terms of sustainability and whole ecosystem effects, the only analysis possible is to impose a non-negativity constraint on all relevant environmental variables. In other words, this type of analysis allows only 'no decline' changes in environmental endpoints. Almost every feasible policy option or project will violate at least one of the non-negativity constraints. Some impact is inevitable with economic activity, it is the catastrophic impact that must be guarded against.

A better operational measure of the environment and sustainability is needed. EMAP attempts to develop overall indicators for individual ecosystems (such as forests, wetlands or estuaries). In the case of estuaries, EMAP develops as series of over twenty indicators, but creates an aggregate index by summing the indicators based on water clarity, the benthic index, and the presence of trash (Schimmel, et al. 1994). This is indicative of a general procedure employed by natural scientists to create aggregate indicators by summing all individual environmental indicators and dividing by the number of indicators to create an unweighted index. This unweighted index is virtually meaningless, because it implicitly and arbitrarily uses equal weights for each individual indicator. For instance, why should a $10 \%$ increase in the benthic index and a ten percent increase in the presence of trash receive the same weight in the index? Additionally, there is a potential problem of the level of the index being a function of the choice of the unit of measurement of each of the individual variables.

One solution might be to use an analog to GDP to create an index to solve these problems. With GDP, the issue of weighting the index is solved implicitly through the prices that the market assigns to goods and services. Here, prices can show the willingness to make clear tradeoffs between the entities and provide a consistent unit of measurement over all variables. However, prices don't exist for many of the most important environmental resources that are essential to the discussion of sustainability. It is necessary to find another method for weighting the variables, but it would be useful if the weights still maintained the property of prices in measuring the willingness to make a trade-off between one variable and another. It is possible to accomplish this goal through the use of survey research methods.?

\footnotetext{
${ }^{7}$ See Kahn (1998) for a complete discussion of using survey methods to develop an indicator of environmental quality.
} 
Although some survey based valuation techniques have been controversial in recent years because of biases introduced in the survey process, new techniques have been developed to correct for many of them. Conjoint analysis enables researchers to estimate environmental value by asking individuals to choose among alternative states of the environment, with different levels of key environmental variables. Preference functions can then be estimated by using the probability of a person's choice as a function of the environmental characteristics embodied in that choice. And finally, the derivative of the preference functions with respect to the individual characteristics can be used as weights to aggregate individual characteristics into an index, producing an environmental index which is analogous to GDP. Indices could be developed at the global, national, regional or local level, and could also be developed for individual types of resources (forests, wetlands, oceans, etc.)

This trade-off weighted index of environmental quality can then be used in shaping environmental policy in several ways. It can simply provide a minimum acceptable level constraint, a kind of baseline around which future policy can be controlled. It could be set as a non-negativity constraint, where no decline in it's value would be allowable in the future. Or it could be used in sensitivity analysis around which different policy option could be evaluated.

Environmental Quality Index

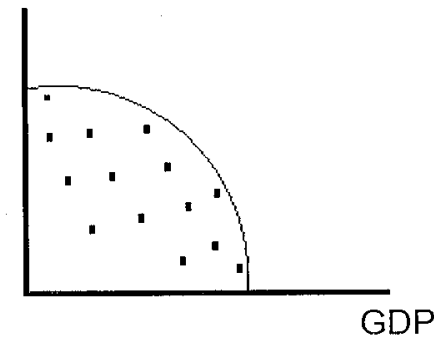

Figure 6 - Sensitivity analysis and the environmental quality index

Figure 6 provides some insight into how this sensitivity analysis could be conducted. Alternative policies could be evaluated with respect to their performance on social indicators, such as GDP and the index of environmental quality. When all the alternative policies are diagramed, an outer envelope of the policies can be drawn which has the same interpretations as the production possibilities frontiers depicted in Figures 3 and 4. Policy options in the interior of the possibilities curve demonstrate inferior policy choices among those available. Policies directly on the frontier are the best in the sense that they have higher levels of both environmental quality and GDP then the policies to the interior. Which of these policies is the best? 
That question can not be answered by this analysis, but the analysis defines a specific trade-off between environmental quality and GDP, and the best position on the frontier would be determined through social dialogue and the political process. It is also possible that the sensitivity analysis might identify policies that are outliers in the sense that they are far to the northeast of the bulk of the other policies, such as the points labeled A and $B$ in Figure 7 . The possibility of these points exists because of the potential positive feedback between the environment and GDP, where increased environmental quality leads to increase GDP.

Environmental Quality Index

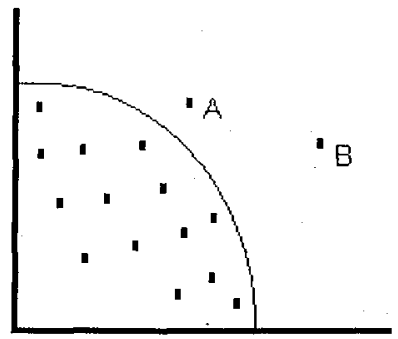

GDP

Figure 7. Sensitivity analysis and the possibility of indentifying outliers

\section{6 - CONCLUSIONS AND MINING RESEARCH AGENDA}

The questions of sustainability in general and sustainability and mining specifically remain complex questions with no easy solutions. However, this paper suggests that sustainability is dependent on the conservation of ecological resources and the maintenance of a flow of ecological services that are important to economic production processes, ecological production processes and to day-to-day living and the quality of life. Since many activities based on the extraction of renewable resources are extremely detrimental to environmental resources, environmentally sound mining may play a key role in sustainable development.

However, it is difficult to implement policies which strive towards sustainable development without developing operational indicators of environmental quality and sustainable development. This paper suggests a method for doing this that consists of four major steps. First, a relevant set of environmental characteristics is defined and placed into scenarios describing alternative states of the environment. Second, survey methods such as conjoint analysis are implemented which ask people make choices between sets of alternative states of the environment that are preferable. In the third step, these data are used to estimate preference functions, which can be 
differentiated with respect to each characteristic to define a trade-off based weight for the characteristic. Finally, the weights can be used to aggregate the characteristics into a single index of environmental quality.

\section{REFERENCES}

BARNETT, Harold J; CHANDLER, Morse. Scarcity and growth, the economics of natural resource availability Johns Hopkins University Press, 1963.

CAVIGLIA, Jill. Economic analysis of sustainable agriculture in the tropical rain forest of Brazil. agricultural techniques in Rondonia. Ph.D. Dissertation, University of Tennessee, 1998

GILLIS, Thomas; MCGARTLAND, Albert; NESTOR, D V.; PASURKA C.; WIGGIN, L. B. The social cost and benefits of air quality management programs a general equilibrium approach. Unpublished paper presented at the Southern Economic Association Meetings, 1996

HARTWICK, John. Intergenerational equity and the investing of rents from exhaustible resources. AER, v. 67, n 5, p.972-4, 1977

The generalized $R \%$ rule for semi-durable exhaustible resources. Resource and Energy Economics, 15, p.147-152, 1993

Sustainability and constant consumption paths in open economies with exhaustible resources. Prepared for AERE Conference, Boulder, CO, 1994

HAZILLA, Michael; KOPP, R. J. Social cost of environmental quality regulations: a general equilibrium analysis. Journal of Political Economy, 98, n. 4, p.853-87, 1990.

JORGESON, Dale W, WILCOXEN, Peter. Intertemporal general equilibrium modeling of U.S. environmental regulation. Journal of Policy Modeling, v. 12, n. 4, p. 715-744, 1990.

KAHN, James $\mathrm{R}_{\text {. }}$, The economic approach to environmental and natural resources. The Dryden Press, $2^{\text {nd }}$ ed., 1998.

Trade-off based indicators of environmental quality: an environmental analogue to GDP. Unpublished paper presented at the Southern Economic Association Meetings, 1996 .

KAHN, James R; O'NEILL, Robert V. Ecosystem stability as a measure of scarcity. Unpublished manuscript presented at the Second Biennial Conference of The Canadian Society for Ecological Economics, 1997.

Ecological interaction as a source of economic irreversibility Unpublished manuscript presented at the Southern Economic Association Meetings, 1997.

MALTHUS, Thomas Robert (1822). An Essay on the principle of population reprinted In: An essay on the principle of population. text, sources and background, criticism, APPLEMAN, Phillip (ed). New York: Norton, 1975.

PEARCE, David W, WARFORD, Jeremy. World without end economics, environment and sustainable development. Oxford University Press, 1993

PEZZEY, John. Economic analysis of sustainable growth and sustainable development. Working Paper 15, World Bank, Environment Department, 1989

PORTER, Michael A. The competitive advantage of nations. Free Press, 1990

RICARDO, D. (1817) Principles of political economy and taxation. Everyman: London, reprint 1926.

SCHIMMEL, Steven C et al Statistical summary: EMAP estuaries. Virginia Province-1991, USEPA, EPA/620/R-94/005, March 1994.

SOLOW, Robert M. An Almost Practical Step Toward Sustainability. Invited Lecture on the Occasion of the Fortieth Anniversary of Resources for the Future, 1992.

TILTON, John E. Exhaustible resources and sustainable development. Resources Policy, 22, p. $91-97$.

WORLD COMMISSION ON ENVIRONMENT AND DEVELOPMENT. Our common future: the Brundtland report. New York: Oxford University Press. 1987. 